\title{
Property Tax Exemption for Government-Owned Real Estate in Mexico
}

\author{
Nicolás Guadalupe Zúñiga Espinoza ${ }^{1 *}$, Marcela Astudillo Moya² \\ ${ }^{1}$ Autonomous University of Sinaloa, Culiacan, Mexico \\ ${ }^{2}$ National Autonomous University of Mexico's Institute for Economic, Mexico City, Mexico \\ Email: *nicozu1@uas.edu.mx
}

How to cite this paper: Espinoza, N.G.Z. and Moya, M.A. (2018) Property Tax Exemption for Government-Owned Real Estate in Mexico. Modern Economy, 9, 67-86. https://doi.org/10.4236/me.2018.91005

Received: November 12, 2017

Accepted: January 8, 2018

Published: January 11, 2018

Copyright (c) 2018 by authors and Scientific Research Publishing Inc. This work is licensed under the Creative Commons Attribution International License (CC BY 4.0).

http://creativecommons.org/licenses/by/4.0/

\begin{abstract}
The purpose of this article is to contribute to reflection on whether or not current policies exempting government-owned real estate from paying property tax are appropriate, from the perspective of Mexican municipal finance laws. This source of public revenue was given to Mexican municipalities in February 1983, so for the past 34 years it has been and remains an unfulfilled promise in terms of tax collection. A number of studies have been published on the economic determinants of property tax in Mexico, but exemptions from this tax have not been studied from a regulatory standpoint; this issue is still unexplored and unaddressed by experts in the field. This paper seeks to answer the following questions: What are the municipal finance laws regarding exemptions of government real estate from property tax? How do property tax exemptions for government real estate limit municipal revenue potential? What other factors have contributed to limiting the revenues generated by this tax?
\end{abstract}

\section{Keywords}

Property Tax, Exemptions, Government Real Estate, Local Finance

\section{Introduction}

The purpose of this paper is to analyze property tax exemptions extended to government-owned real estate in Mexico. This analysis is particularly pertinent at the present time because it offers evidence of the need to reform municipal finance laws to ensure that this tax is more productive, by repealing tax exemptions that should no longer be in effect. Under current financial conditions, municipalities should no longer grant tax subsidies to properties owned by state and federal governments, because these have much more budget leeway for their 
public administration. Municipalities need to strengthen this local source of revenues in order to bolster funding for local public services.

The paper is organized in four sections. The first offers a brief review of the theoretic background on local autonomy and exemptions. The second describes the method, instruments, and primary and secondary sources used to gather the information. The third section presents the empirical evidence, and the fourth presents conclusions.

\section{Local Autonomy and Exemptions}

In Mexican states, local autonomy requires that governments have the power to attend to local interests and certain power of their resources, which in turn requires a measure of fiscal autonomy. But what does fiscal autonomy mean? For Oates, only revenues in which local authorities decide upon the taxable object or event, the tax base and tax rate, can be considered autonomous [1]. For that author, any other arrangement violates the implicit connection between payment of a tax, and the benefit obtained from the public expenditure.

The two basic issues in public revenues are to what extent municipal governments should be self-funding, and by which method should they collect their revenues. From a political standpoint, the greater the degree of revenue autonomy, the greater the capacity for local control. According to the principle of subsidiarity, as in today's European Union, public responsibilities should be entrusted to the authorities closest to the citizens [2]. Furthermore, as Bahl indicates, fiscal autonomy permits a municipal government to determine the size and composition of its budget according to its needs [3].

In practice, one of the essential problems of local public finance is that revenues are limited, because the federal government appropriates the largest. $\mathrm{Mu}$ nicipal governments' economic capacity thus depends on transfers from other spheres of government, compounded by the fact that there are numerous agencies operating in the local sphere that are completely independent of municipal authority [4]. Local governments face serious administrative difficulties in levying taxes, particularly a lack of information on taxpayer income, properties or consumption, making it hard to precisely determine the taxable bases [5]. Tax collection is also more expensive for local governments because they lack economies of scale. Furthermore, state governments decide on the substantive elements of municipal taxes, and municipalities only manage and collect them, so their tax system does not necessarily correspond to their funding needs [6].

Given the growing importance of local administration in recent years, it is indispensable that municipalities have enough revenues to finance their public services and to play their part in economic activity [7]. Local governments are considered capable of promoting local economic growth, for example by providing the necessary infrastructure. But in Mexico, municipal revenues today account for a scant $2 \%$ of total public revenues; $91 \%$ go to the federal government and the remaining $7 \%$ to state governments. Property tax exemptions 
erode one of the few revenue sources available to local governments, so eliminating or curbing these exemptions may restore their capacity to meet the increasingly ambitious goals assigned to them.

\section{Exemptions}

There is no data available in Mexico on how much in taxes are saved from property tax exemptions. Property tax "exemptions vary from state to state but generally include properties owned by all levels of government, although the 1999 constitutional reform abolished the previous exemption of the property of state-owned enterprises (paraestatales)" [8]. Furthermore, each state has its own municipal finance law, which establishes tax abatements for both public and private properties. The latter are granted exemptions by way of tax incentives on productive investment that promotes local economic development.

Mullen states that there are justifications for granting tax exemptions on both public and private property. But the problem is that this may create locational distortions and tend to encourage inefficient use of land-based inputs. Exemptions may [also] increase the regressivity of the property tax [9]. As for exemptions to attract investment, it has been argued that "tax exemption may induce a new company to locate in the municipality, or an established company to expand, [...] but it also reduces government revenues" [10]. Neighboring municipalities may engage in tax competition in an attempt to attract investment by offering subsidies in the form of non-payment of property taxes. In an exploration of this type of tax in the United States, state that "tax competition for economic development has a long history in the United States and its reform appears to be an intractable challenge; there is reason to be optimistic about improving the use of property tax incentives. State governments control local government taxing powers [...] [and can] use property tax incentives for business more effectively" [11].

Bahl, Youngman and Martínez-Vazquez sustain that this type of tax exemption in developing countries, such as Mexico, can lead to tax revenues 2 or 5 times below the levels of developed nations [12]. This problem of municipal public finance in Mexico is explained in Tello as follows: The property tax system is rife with special treatments. Community-owned properties, ejidos and part of the private sector are exempt from the tax (and this type of property represents a very high percentage of a country's root property). Furthermore, affirm Tello, federal facilities like the Ministry of Public Education (SEP), the properties of Mexican Oil (PEMEX), the airports, and the Mexican Social Security Institute (IMSS), and many others, are also assumed to be exempt [13].

In this country, exemptions are partly to blame for the fact that in 2011, municipalities had to rely on federal allocations to fund $67.5 \%$ their public expenditure [14]. This illustrates the exaggerated degree of tax centralism that municipal governments face, and it is very different from the situation in countries like France, where "the main source of revenues of local French collectivities are tax- 
es, which accounted for $47.1 \%$ of total revenues in 2009 " [15]. This tax, which is known as the warhorse of local taxation [16] provides revenues for funding public services in Italy, France and Portugal [17]. In light of these contrasts, a review of the regulatory framework for this tax in Mexico may yield useful information for policymakers.

\section{Method}

This work was developed through qualitative instruments. The authors first reviewed the theory on local autonomy and property taxes, then examined statistics on property tax collection and social welfare indicators published by the $\mathrm{Na}$ tional Institute for Statistics, Geography and Informatics [18]. A total of $32 \mathrm{mu}$ nicipal finance laws were identified and information as also drawn from the webpages of 32 Mexican states. Information was compiled on the number of properties that are exempt from tax, the amount of taxes exempted, and effective collection, through e-mails, phone calls and contact with municipal authorities ${ }^{1}$.

The sample is not intended to be representative, as not all local government webpages contain information on exemptions. Nationwide data was unavailable because it is not published by INEGI, which made municipal governments more useful sources of information. This limited the data available on the number of exempt properties to those provided for the municipalities of four states in northwestern Mexico which belong to zone one, of the eight work tables of the current National Tax Coordination System. The analysis of the property taxes exemptions is absent from the literature in Mexico, Tello only refers to that it is rife of special treatments [13]. This paper, with a small sample, represents only the first advance in the empirical study of property tax exemptions extended to government-owned real estate in this country.

\section{Empirical Evidence. Review of the Regulatory Framework and Data}

This paper argues that eliminating property exemptions for government properties and thus increasing revenues from this source would enable local governments to depend less on federal and state allocations and to fund public services through local taxes. It would also fortify accountability for elected officials now in office, and according to Haughwout and Inman, misconduct in the management of local public finance causes both companies and people to migrate out of territories [19]. This was the motivation for main reforms by which this tax was de-centralized in the past.

\subsection{The 1983, 1999 and 2013 Reforms to Increase Tax Collection}

For Bird and Slack, property tax revenues rarely account for more than 3 percent

${ }^{1}$ The authors are grateful to the public officials of the municipal property tax departments of Baja California and the Cadastral Institute of Sonora for providing this information (November and December 2014). Data from Sinaloa were obtained from Publication 169, Praxis series. 
of a country's GDP [8]. The most recent data for Mexico indicate that in the year 2013, according to data from the OECD (2016) (see Appendix), it was barely 0.2 percent [20]. In this country, reforms to article 115 of the constitution in 1983 and 1999, the first of which decentralized property tax to the municipal level, have not borne the expected fruit. Regulations permitting exemptions of this tax have been based on the resolution published in the Official Gazette of the Federation (OGF), amending article 115 of the Mexican constitution read in part: federal law may not limit the faculty of local governments to impose real-estate property taxes nor to grant exemptions. Local laws may not establish exemptions or subsidies with respect to private companies or individual; only property in the public domain of the Federation, of the States or Municipalities, may be exempted from those taxes [21].

In an effort to amend the poor results and increase from this tax, the 1999 reform added an exemption, that read: "...unless those goods are used by stateowned enterprises or private parties, in any form, for administrative ends or purposes other than those inherent to its public purpose." This reform was intended to force state-owned enterprises to pay taxes, bolstering local governments' limited taxation capacities [22].

But hard data from the OECD shows us that in 2014, property tax collection amounted to 0.32 (see Graph 1) percent of GDP, the clearest evidence that the 1983 and 1999 reforms to constitutional article 115 did not have the intended effect, and that revenues continued to stagnate [23]. The reform failed to give municipal governments control over the fees, rates and the land and building assessment value tables that would enable them to collect taxes due on these properties. In actual practice, the Mexican municipality today continues to lack taxation powers.

\subsection{Recent Diagnosis}

Aware of this historical scarcity of local sources revenues for Mexico's muni-

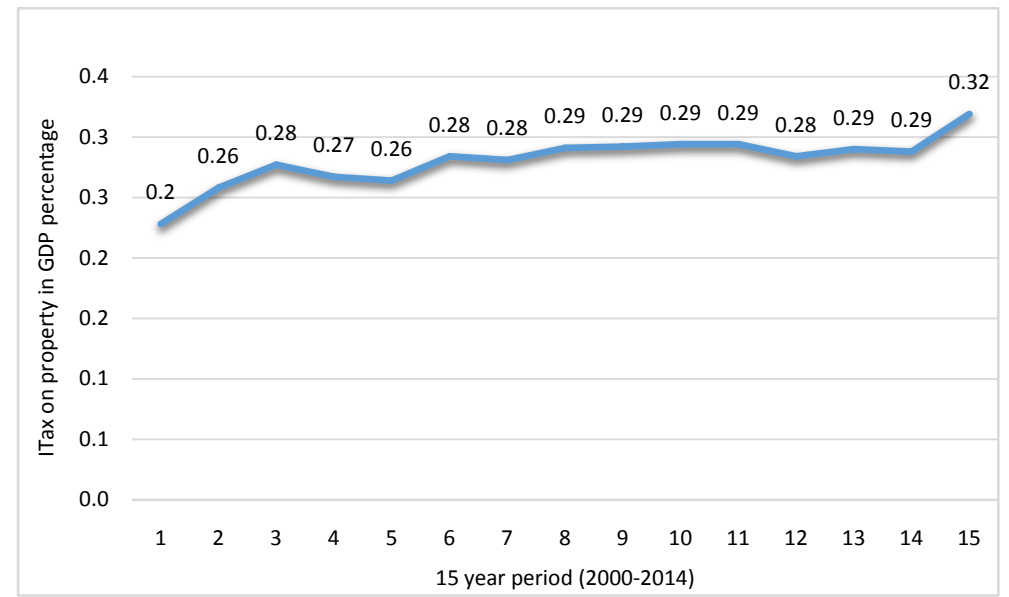

Graph 1. Mexico property tax (2000-2014). Source: Author's elaboration with database of the OECD (2017) Tax on Property, https://data.oecd.org/tax/tax-on-property.htm. 
cipal governments, the federal executive branch designed a public policy focused on improving the performance of this tax. This consisted of the addition of an article 2-A to the Tax Coordination Law (TCL) which provided for a new way of distributing the Municipal Promotion Fund (MPF) [24]. This fund had in the past been distributed completely in accordance with tables on property tax and water rights collections data. With the 2013 reform, starting in 2015 these funds would be distributed "70 percent by the same criteria and 30 percent according to the revenues generated from property taxes, provided the government of each state is responsible for collecting the property tax on behalf of the municipality" [25]. It remains to be seen whether this adjustment to the TCL will actually improve the productivity of property taxes, because one particularly power full imitation is the exemption granted to government buildings.

\subsection{Exploring Municipal Finance Legislation}

Having analyzed the theory and background of property tax performance in the preceding section, particularly in federal legislation, this section turns its focus to the content of municipal finance law with regard to property tax exemptions for government buildings.

No statistics are available on the precise amount of tax lost by income tax exemptions for each state, but a state-by-state review of local regulations can provide some insight into the sources of revenue not being exploited in each. Table 1 shows the municipal finance laws of 31 states and the Federal District (now called Mexico City). The second column cites the article on payment of property tax, the third shows the type of government property exempt from payment, and the fourth shows the requirement(s) to qualify for the exemption. There is one exception, the state of Morelos, in which the 2014 Municipal Finance Law, article $93 \mathrm{~b}$ is 2, establishes that "property tax is due upon the ownership or possession of land located within municipal territory, regardless of its use or purpose" [26]. The findings of this paper suggest that this would be ideal for all municipalities in Mexico-in other words, that all properties should be subject to taxes regardless of who owned them, which would infuse new life into municipal public finances.

In the state of Campeche, in addition to public property exemptions, article 28 of the local finance law allows for exemptions on property acquired by family inheritance, as defined in the Civil Code of that state.

In another three states-Chiapas, Hidalgo and Tabasco-a written request is needed in order for public property to qualify for a property tax exemption. In Hidalgo, owners must submit a request to the Municipal Treasury within 30 days after receiving a tax collection notice. In Tabasco, besides the written request, owners must attach the corresponding proof to be analyzed by the person in charge of municipal tax policy.

In Mexico City, exemption must also be requested in writing by the property owner, and it must be renewed every 5 years. In Durango, federal and state gov- 
Table 1. Exemptions for government properties.

\begin{tabular}{|c|c|c|c|}
\hline \multicolumn{4}{|c|}{ Analysis of Mexican Municipal Finance Laws ${ }^{*}$} \\
\hline State & Article & Exempt properties & Requirement \\
\hline Aguascalientes & 4. & Public property & Proven ownership \\
\hline Baja California & 75-bis-a & Public property & $\begin{array}{l}\text { Public property used for other purposes } \\
\text { is subject to tax }\end{array}$ \\
\hline Baja California Sur & 24 & Public property & $\begin{array}{l}\text { Public property used for other purposes } \\
\text { is subject to tax }\end{array}$ \\
\hline Campeche & 28 & Public property and family inheritance & Family inheritance as defined in the State Civil Code \\
\hline Coahuila & 29 & Public property & $\begin{array}{l}\text { Public property used for other purposes } \\
\text { is subject to tax }\end{array}$ \\
\hline Colima & 19 & Public property & $\begin{array}{l}\text { Public property used for other purposes } \\
\text { is subject to tax }\end{array}$ \\
\hline Chiapas & 13 and 14 & Public property & Exemption must be requested in writing \\
\hline Chihuahua & 150 & Public property & $\begin{array}{l}\text { Public property used for other purposes } \\
\text { is subject to tax }\end{array}$ \\
\hline $\begin{array}{l}\text { Federal District } \\
\text { (Mexico City) }\end{array}$ & 133 & $\begin{array}{l}\text { Public property of the federal government, } \\
\text { de-centralized city government agencies, } \\
\text { diplomatic representations of foreign states and } \\
\text { International Organizations of which the } \\
\text { Mexican government is a member }\end{array}$ & $\begin{array}{l}\text { Exemption must be requested and must } \\
\text { be renewed every } 5 \text { years }\end{array}$ \\
\hline Durango & 20 & $\begin{array}{l}\text { Public property, property of foreign governments } \\
\text { and others established by international treaties } \\
\text { currently in effect regarding reciprocal tax } \\
\text { treatment with those countries }\end{array}$ & $\begin{array}{l}\text { Proof of eligibility required when } \\
\text { municipality has questions about the property }\end{array}$ \\
\hline Guanajuato & 161 & Public property & $\begin{array}{l}\text { Public property used for other purposes } \\
\text { is subject to tax }\end{array}$ \\
\hline Guerrero & 11 & Public property & $\begin{array}{l}\text { Public property used for other purposes is subject to } \\
\qquad \operatorname{tax}\end{array}$ \\
\hline Hidalgo & 12 & $\begin{array}{l}\text { Public property when used to provide a public } \\
\text { service }\end{array}$ & $\begin{array}{l}\text { Exemption must be requested from the } \\
\text { Municipal Treasury within } 30 \text { days after the } \\
\text { authority issues the collection notice }\end{array}$ \\
\hline Jalisco & 104 & Public property & $\begin{array}{l}\text { Public property used for other purposes } \\
\text { is subject to tax }\end{array}$ \\
\hline State of Mexico & 5 & $\begin{array}{l}\text { Public property, accredited by means of } \\
\text { the corresponding certification }\end{array}$ & $\begin{array}{l}\text { Public properties owned by federal state-owned } \\
\text { enterprises are not exempt unless involved } \\
\text { in educational activity }\end{array}$ \\
\hline Michoacán & 25 & Public property & $\begin{array}{l}\text { Public property used for other purposes } \\
\text { is subject to tax }\end{array}$ \\
\hline Morelos & 93-bis-2 & No exemptions & All properties are subject to tax \\
\hline Nayarit & 16 & $\begin{array}{l}\text { Property exploited directly by any of } \\
\text { the } 3 \text { levels of government }\end{array}$ & $\begin{array}{l}\text { All properties are subject to tax except those exploited } \\
\text { directly by Federal, State and Municipal governments }\end{array}$ \\
\hline Nuevo León & 21-bis & Public property & $\begin{array}{l}\text { Public property used for other purposes } \\
\text { is subject to tax }\end{array}$ \\
\hline Oaxaca & 18 & Public property & $\begin{array}{l}\text { Public property used for other purposes } \\
\text { is subject to tax }\end{array}$ \\
\hline
\end{tabular}




\section{Continued}

\begin{tabular}{|c|c|c|c|}
\hline Puebla & 13 & Public property & $\begin{array}{l}\text { Public property used for other purposes } \\
\text { is subject to tax }\end{array}$ \\
\hline Querétaro & 22 & Public property & $\begin{array}{l}\text { Public property used for other purposes } \\
\text { is subject to tax }\end{array}$ \\
\hline Quintana Roo & 6 & $\begin{array}{l}\text { Public property as defined in the General } \\
\text { Law on National Property }\end{array}$ & $\begin{array}{l}\text { Public property used for other purposes } \\
\text { is subject to tax }\end{array}$ \\
\hline San Luis Potosí & 18 & Public property used to provide a public service & $\begin{array}{l}\text { Public property used for purposes other } \\
\text { than its public purpose is subject to tax }\end{array}$ \\
\hline Sinaloa & 38 & $\begin{array}{l}\text { Public property and property owned by worker or } \\
\text { peasant unions may qualify for a deduction of } \\
16,500 \text { times the minimum wage }\end{array}$ & $\begin{array}{l}\text { Public property used for other purposes } \\
\text { is subject to tax }\end{array}$ \\
\hline Sonora & 24 & $\begin{array}{l}\text { Public property; in the event that ownership is } \\
\text { questionable, the municipality may request the } \\
\text { corresponding certification }\end{array}$ & $\begin{array}{l}\text { Public property used for other purposes } \\
\text { is subject to tax }\end{array}$ \\
\hline Tabasco & 104 & $\begin{array}{c}\text { Public property of the Federation that is listed in } \\
\text { the National Property Registry. State and } \\
\text { Municipal Property. }\end{array}$ & $\begin{array}{l}\text { Exemptions must be requested in writing, } \\
\text { with the corresponding evidence attached }\end{array}$ \\
\hline Tamaulipas & 123 & Public property & $\begin{array}{l}\text { Public property used for other purposes } \\
\text { is subject to tax }\end{array}$ \\
\hline Tlaxcala & 200 and 201 & $\begin{array}{l}\text { Public property and persons in obvious state of } \\
\text { poverty may qualify for a discount of up to } 75 \\
\text { percent of the tax, subject to municipal } \\
\text { council approval }\end{array}$ & $\begin{array}{l}\text { Public property used for other purposes } \\
\text { Is subject to tax, and } 25 \text { percent of the tax must be } \\
\text { paid by persons in an obvious state of poverty. }\end{array}$ \\
\hline Veracruz & 119 & Public property & $\begin{array}{l}\text { Public property used for other purposes } \\
\text { is subject to tax }\end{array}$ \\
\hline Yucatán & 48 & Public property & $\begin{array}{l}\text { Public property used for other purposes } \\
\text { is subject to tax }\end{array}$ \\
\hline Zacatecas & 13 & $\begin{array}{l}\text { Public property, de-centralized agencies used for } \\
\text { infrastructure and industrial units, as well as } \\
\text { political parties }\end{array}$ & $\begin{array}{l}\text { The state property tax assessment office will } \\
\text { conduct technical studies to identify those properties. }\end{array}$ \\
\hline
\end{tabular}

Source: Appendix. Author's preparation based on a query regarding 32 municipal finance laws in effect in the states of Mexico, as researched in November 2014. *In México City (formerly Distrito Federal, now Ciudad de México) it is called the Tax Code; in Tamaulipas and Chihuahua the Municipal Code; in Tlaxcala the Financial Code; and in Veracruz the Public Finance Code (Appendix).

ernments must prove they own the buildings in order to qualify for the exemption. In Morelos, only state-owned government property used for the purposes of educational activity is exempt from property tax.

In Nayarit, the law considers all properties subject to tax, except for those exploited directly by the federal, state and municipal governments; and in San Luis Potosi, public property used for any other than its public purpose is subject to tax.

There are twenty states in which municipal governments, in keeping with their respective municipal finance laws, obligate governments to pay tax on properties used for other than public purposes. These are:Baja California, Baja California Sur, Coahuila, Colima, Chihuahua, Guanajuato, Guerrero, Jalisco, Michoacán, Nuevo León, Oaxaca, Puebla, Querétaro, Quintana Roo, Sinaloa, Sonora, Tamaulipas, Tlaxcala, Veracruz and Yucatán.Finally, in Zaca- 
tecas, the state cadastral office is responsible for identifying property that is tax exempt.

Municipalities, also offer partial exemptions, established not only in local finance laws but in other laws such as economic development regulations involving tax competition to attract investments ${ }^{2}$, but these are beyond the scope of this paper.

\subsection{Property Tax Collection by State}

As Table 2 shows, in the year 1989, property tax collection in Mexico totaled 415 million pesos, 31 percent of which came from Mexico City. In 1996, property tax revenues totaled 5188 million pesos, and all of the states together, excluding Mexico City, contributed less than half of this amount-barely 46 percent of the total. In 2012, once again, Mexico City accounted for the lion's share of property tax revenues, with 67 percent of the 31,542 million pesos collected by the local governments of our country.

During 2014, the government of Mexico City brought in tax revenues of around 39,898 million pesos, of which about 29 percent were from property taxes [27]. (El Universal, 2015). The strong performance of public revenue collection may have been the result of a December 2013 amendment to the article 127 of the Mexico City Tax Code (2014) indicating that "the tax base for property tax shall be the assessed value determined by taxpayers [...] according to the market value of the property" [28]. The rest of the Mexican states continue to calculate property tax based on the official assessment of the land registry office. So the government of Mexico City collects, nationwide, proportionally more of the total property taxes.

\subsection{Some Data on Exemptions: Northwest Mexico}

How do property tax exemptions for government properties limit tax revenue potential for local governments? The theoretic section of this paper notes that there is no data available on the amount of expenditure the government saves by not paying this tax. Each state has its own municipal finance law, which includes property tax exemptions or abatements for public or private property. Ideally, there would be statistical data for each municipality, but given the exiting limitations this paper focuses on data from municipalities in northwestern Mexico, except Baja California Sur to illustrate the limitations posed by property tax exemptions.

In the case of Sonora, exemptions of government property account for 5 percent of the total value of the properties listed in municipal land registries (see Table 3). These tax benefits extended to government properties are an indicator of the impact they have on municipal fiscal health.

Baja California Sur did not provide information on exemptions, so for this

${ }^{2}$ For example, tax stimulus offered by the Law to Promote Investment for the Economic Development of Sinaloa (2014). 
Table 2. Property tax revenues.

\begin{tabular}{|c|c|c|c|c|c|}
\hline \multicolumn{6}{|c|}{ PROPERTY TAX REVENUES IN MEXICO, 1989-2016 (IN CURRENT PESO TERMS) } \\
\hline \multicolumn{3}{|c|}{ STATES } & \multicolumn{2}{|c|}{ MEXICO CITY } & \multirow[b]{2}{*}{$\begin{array}{l}\text { HISTORIC } \\
\text { REVENUES }\end{array}$} \\
\hline YEAR & REVENUES & $\begin{array}{c}\text { CENTS } \\
\text { COLLECTED } \\
\text { PER PESO } \\
\text { TOTAL }\end{array}$ & REVENUES & $\begin{array}{c}\text { CENTS } \\
\text { COLLECTED } \\
\text { PER PESO } \\
\text { TOTAL }\end{array}$ & \\
\hline 1989 & $284,443,174$ & 0.69 & $130,619,000$ & 0.31 & $415,062,174.00$ \\
\hline 1990 & $554,406,818$ & 0.54 & $478,452,000$ & 0.46 & $1,032,858,818.00$ \\
\hline 1991 & $802,977,307$ & 0.48 & $872,684,000$ & 0.52 & $1,675,661,307.00$ \\
\hline 1992 & $1,181,154,140$ & 0.49 & $1,211,195,000$ & 0.51 & $2,392,349,140.00$ \\
\hline 1993 & $1,531,187,378$ & 0.52 & $1,432,937,100$ & 0.48 & $2,964,124,478.00$ \\
\hline 1994 & $1,817,525,883$ & 0.52 & $1,663,687,100$ & 0.48 & $3,481,212,983.00$ \\
\hline 1995 & $1,853,555,090$ & 0.49 & $1,954,450,700$ & 0.51 & $3,808,005,790.00$ \\
\hline 1996 & $2,409,508,883$ & 0.46 & $2,779,350,400$ & 0.54 & $5,188,859,283.00$ \\
\hline 1997 & $2,753,448,740$ & 0.47 & $3,119,348,600$ & 0.53 & $5,872,797,340.00$ \\
\hline 1998 & $3,331,994,772$ & 0.47 & $3,711,137,100$ & 0.53 & $7,043,131,872.00$ \\
\hline 1999 & $3,984,004,977$ & 0.48 & $4,335,692,000$ & 0.52 & $8,319,696,977.00$ \\
\hline 2000 & $4,709,963,392$ & 0.47 & $5,237,645,800$ & 0.53 & $9,947,609,192.00$ \\
\hline 2001 & $5,873,314,808$ & 0.49 & $6,124,813,300$ & 0.51 & $11,998,128,108.00$ \\
\hline 2002 & $7,037,748,304$ & 0.53 & $6,235,608,700$ & 0.47 & $13,273,357,004.00$ \\
\hline 2003 & $7,728,543,640$ & 0.54 & $6,572,721,800$ & 0.46 & $14,301,265,440.00$ \\
\hline 2004 & $9,113,164,107$ & 0.59 & $6,319,733,800$ & 0.41 & $15,432,897,907.00$ \\
\hline 2005 & $10,098,057,336$ & 0.61 & $6,543,600,700$ & 0.39 & $16,641,658,036.00$ \\
\hline 2006 & $11,557,469,167$ & 0.64 & $6,601,481,000$ & 0.36 & $18,158,950,167.00$ \\
\hline 2007 & $12,703,277,660$ & 0.65 & $6,721,752,500$ & 0.35 & $19,425,030,160.00$ \\
\hline 2008 & $14,453,531,617$ & 0.68 & $6,940,635,600$ & 0.32 & $21,394,167,217.00$ \\
\hline 2009 & $15,649,210,522$ & 0.68 & $7,212,846,700$ & 0.32 & $22,862,057,222.00$ \\
\hline 2010 & $17,201,814,521$ & 0.67 & $8,521,626,800$ & 0.33 & $25,723,441,321.00$ \\
\hline 2011 & $18,986,658,283$ & 0.66 & $9,741,473,000$ & 0.34 & $28,728,131,283.00$ \\
\hline 2012 & $21,063,542,298$ & 0.67 & $10,479,070,000$ & 0.33 & $31,542,612,298.00$ \\
\hline 2013 & $20,993,506,966$ & 0.67 & $10,344,662,900$ & 0.33 & $31,338,169,866.00$ \\
\hline 2014 & $25,843,313,282$ & 0.69 & $11,849,930,700$ & 0.31 & $37,693,243,982.00$ \\
\hline 2015 & $23,715,493,533$ & 0.63 & $14,187,482,800$ & 0.37 & $37,902,976,333.00$ \\
\hline 2016 & $19,235,641,702$ & 0.58 & $14,120,065,117$ & 0.42 & $33,355,706,819.00$ \\
\hline
\end{tabular}

Source: Author's preparation based on data from National Institute of Statistics and Geography [INEGI] (2016), document avaible on line at

http://www.inegi.org.mx/sistemas/olap/Proyectos/bd/continuas/finanzaspublicas/FPMun.asp?s=est\&c=112 89\&proy=efipem_fmun (tables for 2016 are preliminary). 
Table 3. Property tax exemptions in Northwestern Mexico.

\begin{tabular}{|c|c|c|c|c|c|c|}
\hline \multicolumn{7}{|c|}{ Properties, Exemptions and Property Tax Collection in Northwest Mexico, 2014} \\
\hline \multicolumn{4}{|c|}{ Properties } & \multicolumn{2}{|c|}{$\begin{array}{l}\text { Exemptions and Tax Collection } \\
\text { (pesos) }\end{array}$} & \multirow[b]{2}{*}{$\begin{array}{c}\text { Proportion of } \\
\text { exempt/effective tax } \\
\text { collection }\end{array}$} \\
\hline State & $\begin{array}{c}\text { Number } \\
\text { of } \\
\text { properties }\end{array}$ & Exemptions & $\begin{array}{c}\text { Percentage } \\
\text { exempt }\end{array}$ & $\begin{array}{l}\text { Revenues } \\
\text { exempt }\end{array}$ & $\begin{array}{l}\text { Effective tax } \\
\text { collection }\end{array}$ & \\
\hline $\begin{array}{c}\text { Baja } \\
\text { California } \\
\text { Baja }\end{array}$ & $1,328,292$ & 18,694 & 1.41 & $83,019,711$ & $562,097,779$ & $15 \%$ \\
\hline $\begin{array}{l}\text { California } \\
\quad \text { Sur }\end{array}$ & nd & nd & nd & nd & $334,796,374$ & nd \\
\hline Sinaloa & 957,598 & 32,558 & 3.40 & $182,083,854$ & $1,171,619,827$ & $16 \%$ \\
\hline Sonora & $1,135,617$ & 61,614 & 5.43 & $281,147,997$ & $764,205,858$ & $37 \%$ \\
\hline Total & $3,421,507$ & 112,866 & 3.30 & $546,251,562$ & $2,832,719,838$ & $19 \%$ \\
\hline
\end{tabular}

Source: information obtained by phone and e-mail in November and December 2014 from staff at the Land Registry Institute of Sonora and the Municipal Land Registry of Baja California. Data on Sinaloa were obtained from the Forum of Public Administrators held by INAP in September 2015. Tax collection tables were obtained from the webpage of INEGI (State and Municipal Public Finance Statistics).

state we have only the tables from INEGI (2014) on property tax collection. In Sinaloa, for example, there were 32,558 properties owned by the three levels of government, that did not pay property tax. In addition, articles 38, 43 and 44 of the Municipal Finance Law of Sinaloa (2014) grants a partial tax exemption to labor and peasant unions, and a 50 and 40 percent abatement for owners in the residential and commercial sectors, respectively [29]. This has reduced total tax revenues for Sinaloa, which in turn receives less from the Municipal Promotion Fund, obligating the state to keep its vehicle use and ownership tax in place.

All totaled, in fiscal year 2014, in the states of northwest Mexico, excluding Baja California Sur, exemptions were granted to 112,866 government properties, equivalent to 3 percent of the tax rolls, which meant giving up revenues of a little over 546 million pesos. This amount of uncollected revenue would have been useful considering the budget cuts that governments have had to endure in the past two years due to the plunge in oil prices and its impact on public finances in Mexico.

The next question is how these exemptions have hurt municipal revenue collection. In the state of Sonora, for example, 61,614 properties are exempt from payment of property tax pursuant to Article 24 of that state's Municipal Finance Law. These properties, through representing a scant 5.4 percent of the property tax rolls, contribute absolutely nothing to local public expenditures. The land registry assessment-not the market value-of the exempt properties of Sonora in 2014 totaled 20,903 million pesos, which means 281 million pesos in lost revenues.

Article 24 of the 2014 Sonora's Municipal Finance Law also establishes that when municipal authorities are unsure whether or not a property is public, they must request the corresponding evidence from the competent authorities. If it is 
not public property, then the municipal government, through the Treasury, will proceed to revoke the exemption and request payment of property tax, effective as of the date it is proven to have a different use [30].

A full set of data was available from the state of Baja California, and sources interviewed phone said that its municipalities administer the land registry directly, as the attribute is municipal by nature, not state or federal. In this state some 18,694 properties are exempt (see Table 4), representing 1.4 percent of the total, and the municipality of Ensenada, for example, extends property tax emptions to 2037 properties, Mexicali to 5,790, Tijuana to 8,961, Playas de Rosarito to 982 and Tecate to 924 , which represent 1.1, 1.4, 1.5, 1.1 and 1.4 percent of the tax rolls of each respective municipality. Baja California's 2015 Municipal Finance Law allows exemption from payment of tax on tax public property at the federal, state or municipal level, except when the property is used by private agents or state-owned enterprises for ends other than its public purpose [31].

This data property tax exemptions in these states of Mexico reveals that, despite the constitutional reforms to article 115 in 1983 and 1999, there has been no improvement in the performance of municipal property tax revenues. The exception would be Mexico City, which in 2014 obtained strong returns from its property taxes, because starting in that year it began calculating the tax rate based on the market value of the property instead of the land registry assessment, based on changes in its tax code (2014). This experience might be usefully applied by municipalities in the other states of Mexico.

\subsection{Other Factors That Limit Tax Collection}

Having examined in the previous section the impact of property tax exemptions for government properties, this section reviews other factors, particularly

Table 4. Property tax exemptions in baja california.

\begin{tabular}{|c|c|c|c|c|c|c|}
\hline \multirow[b]{2}{*}{ Municipality } & \multirow[b]{2}{*}{$\begin{array}{l}\text { Number of } \\
\text { properties }\end{array}$} & \multicolumn{2}{|l|}{ Properties } & \multicolumn{2}{|c|}{$\begin{array}{l}\text { Exemptions and Tax } \\
\text { Collection (pesos) }\end{array}$} & \multirow[b]{2}{*}{$\begin{array}{l}\text { Proportion of } \\
\text { exempt/effective } \\
\text { tax collection }\end{array}$} \\
\hline & & Exemptions & $\begin{array}{l}\text { Percentage } \\
\text { exempt }\end{array}$ & $\begin{array}{c}\text { Revenues } \\
\text { exempt }\end{array}$ & $\begin{array}{l}\text { Effective tax } \\
\text { collection }\end{array}$ & \\
\hline Ensenada & 182,524 & 2,037 & 1.12 & $9,294,831$ & $77,569,493$ & $12 \%$ \\
\hline Mexicali & 413,628 & 5,790 & 1.40 & $26,419,770$ & $174,812,409$ & $15 \%$ \\
\hline Tijuana & 578,743 & 8,961 & 1.55 & $40,889,043$ & $244,512,534$ & $17 \%$ \\
\hline $\begin{array}{l}\text { Playas de } \\
\text { Rosarito }\end{array}$ & 87,397 & 982 & 1.12 & $2,199,855$ & $37,098,454$ & $6 \%$ \\
\hline Tecate & 66,000 & 924 & 1.40 & $4,216,212$ & $28,104,889$ & $15 \%$ \\
\hline Total & $1,328,292$ & 18,694 & 1.41 & $83,019,711$ & $562,097,779$ & $15 \%$ \\
\hline
\end{tabular}

Source: Information obtained by phone and e-mail in November and December 2014 from staff at the Land Registry Institute of Sonora and the Municipal Land Registry of Baja California. Data on Sinaloa were obtained from the Forum of Public Administrators held by INAP in September 2015. Tax collection tables were obtained from the webpage of INEGI (State and Municipal Public Finance Statistics). 
socioeconomic ones, that limit the hidden potential of property taxes.

Social welfare indicators were analyzed for the same states as those examined in the previous section (INEGI, 2014), and reveal that the tax problem, particularly property tax, correlates with other more deep-rooted variables like per capita household income, unemployment, poverty and extreme poverty, in Mexican municipalities. The four states of northwest Mexico show a marked disparity in income, as evident in the Gini coefficient (see Table 5): approximately a third of the population lives in poverty and the rate of informal employment averages $43 \%$. High rates of poverty and unemployment be assumed to have a negative impact, both in terms of tax collection-because they indicate that a substantial portion of the publication is not in a very good position to pay taxesand in terms of the pressure they put on the demand for public services.

Other issues that exert pressure on municipal governments on the spending side are the types of housing and access to basic services, as shown in Table 6. In Sinaloa, only $89 \%$ of homes are equipped with basic services (plumbing, sewage, electricity), and only $49.5 \%$ of homes were roofed in a resistant material. Thus, compounding the problem of limited property tax collection revenues is the pressing need for public assistance and infrastructure to improve quality of life in the municipality.

The data presented in this section attest to the variety of factors that cause

Table 5. Income, poverty and labor informality.

\begin{tabular}{ccccc}
\hline \multicolumn{5}{c}{ Social Welfare Indicators of Northwest Mexico, 2014 } \\
\hline State & $\begin{array}{c}\text { Gini coefficient of } \\
\text { household income per capita }\end{array}$ & $\begin{array}{c}\text { Poverty } \\
\text { rate }\end{array}$ & $\begin{array}{c}\text { Extreme } \\
\text { poverty rate }\end{array}$ & $\begin{array}{c}\text { Labor } \\
\text { informality rate }\end{array}$ \\
\hline $\begin{array}{c}\text { Baja } \\
\text { California } \\
\text { Baja }\end{array}$ & 0.434 & 28.6 & 3.1 & 39.55 \\
$\begin{array}{c}\text { California Sur } \\
\text { Sinaloa }\end{array}$ & 0.454 & 30.3 & 3.9 & 41.05 \\
Sonora & 0.486 & 39.4 & 5.3 & 50.27 \\
National & 0.476 & 29.4 & 3.3 & 44.09 \\
\hline
\end{tabular}

Source: Social Welfare Indicators by State (2014), INEGI, retrieved May 10, 2016.

Table 6. Housing.

\begin{tabular}{ccc}
\hline \multicolumn{3}{c}{ Social Welfare Indicators of Northwest Mexico, 2014 } \\
\hline State & Homes roofed in resistant material (\%) & Homes with basic services \\
\hline Baja California & 49.5 & 89.7 \\
Baja California Sur & 74.8 & 89.9 \\
Sinaloa & 90.1 & 89 \\
Sonora & 67.2 & 93.8 \\
National & 71.6 & 81.8 \\
\hline
\end{tabular}

Source: Social Welfare Indicators by State (2014), INEGI, retrieved May 10, 2016. 
property tax revenues to be mediocre and unproductive for local governments ${ }^{3}$. These include poor technical quality of the land registries ${ }^{4}$ and scarcity of available resources. Most clearly, however, the 32 municipal finance laws of all the states afford a preferential treatment to buildings owned by municipal, state and federal governments, which not only means a greater loss of collected taxes, but an unequal burden for those who do pay property tax.

\section{Recommendations}

Impose budget coordination rules by which federal and state governments must compensate municipalities for at least 20 percent of the amount of tax revenue they would have received on exempt properties. This is consistent with the 20 percent that each state's General Participation Fund allocates to its municipalities, pursuant to the Federal Tax Coordination Law.

The additional revenues municipalities would receive to offset the exemptions should be earmarked for:

1) Improving local taxation system through measures such as personnel training and new technology to make property tax administration more efficient.

2) Evaluating whether the property tax is bing properly administered since 2015, which was the year in which municipalities signed an agreement with state governments to help them boost property tax collection.

3) Funding the implementation of systems for incorporating and updating information on formal and informally owned property in the land registry in order to augment and improve it, as this is the main source of tax and non-tax information on public and private property.

\section{Conclusions}

Despite the limitations imposed by the lack of data on tax collection in all Mexican municipalities, this paper has endeavored to provide a descriptive analysis of property tax exemption policies toward government properties, from the perspective of municipal finance law. The findings illustrate the need to eliminate this type of tax privilege in order to strengthen local autonomy and make it easier to identify taxable property, determine the tax base and set the tax rate. In keeping with the principle of subsidiarity, public officials in charge of collecting municipal taxes and providing local goods and services in Mexico should be administered by the authorities who are closest to the people served.

A review of municipal finance laws from state to state show that the exemptions vary. Despite the 1983 and 1989 amendments to article 115 of the Constitution, and more recently, in 2013, to the Federal Tax Code, tax collection has been stagnating for three decades. In fiscal year 2012, Mexico City was responsi-

${ }^{3}$ For the purposes of this article, the term "local governments" refers to sub-national governments of all kinds.

${ }^{4}$ In general, México's land registry institutes, both those administered by state governments and those administered by municipalities, are woefully out of date in the data reflected on their tax rolls and the assessed property values. 
ble for 67 percent of the property tax collected in Mexico, not because it eliminated this type of exemption, but because it updated its tax base to reflect the market value of properties.

Our search for data on tax exemptions was fruitful for three states: Baja California, Sonora and Sinaloa, which together extended special treatment to almost 113,000 government properties, equivalent to 3 percent of the tax rolls, and which cost their municipal treasuries revenues of a little more than 546 million pesos. But we also found other more deep-rooted variables, like household income per capita, unemployment, poverty and extreme poverty, which limit the potential of this tax for Mexican municipalities.

Obtaining data on the total number of properties listed in municipal and/or state land registries for the entire nation is a very complex task, and the literature is notably absent on this point. Finding out how many of those properties are tax exempt is even more difficult. For this reason, the intent of this paper was to contribute some evidence of the impact of these exemptions on local revenues for municipal governments in northwest Mexico, but from the regulatory rather than the economic standpoint, because the latter has already been done through econometric models.

The analysis presented here reveals a need to overhaul municipal finance laws in order to suspend property tax exemptions for government real estate and thus take advantage of the hidden potential of that tax. It also shows that the fiscal situation is linked to trends in social welfare indicators, including per capita income, unemployment, poverty and extreme poverty, in Mexican municipalities. To overcome the limitations imposed on municipal revenues by these exemptions a fair solution would be to pay some compensatory fee to municipalities from the other two spheres of government, based on the subsidies extended to them through the property tax exemption, such as what is done in Canada (Bird and Slack, 2004).

The tax problems of Mexican municipal governments cannot be attributed solely to the problem of exemptions. There are other factors, like the size and composition of public spending, the provision of public services, the tax rate, payment schedule, absence of professionally-trained public services, and in general, the way in which public finances are administered at this level of government.

There is considerable room for further research in this field, addressing questions such as: What percentage of property tax revenues are allocated to providing public services to the taxed properties? Are tax problems the result of the unproductivity of the tax, or are they caused by inefficient spending practices among public servants or politicians? What should the exemption policy be? Answering these and other questions might be useful in illuminating the difficult path that the property tax has followed throughout its history in the field of Mexican municipal public finance. In order to carry out the future research, disaggregated statistics are required on the collection of property taxes from the 
2446 municipalities of the country, which unfortunately are not currently available.

\section{References}

[1] Oates, W.E. (1977) Federalismo Fiscal. Instituto de Estudios de Administración Local. Nuevo Urbanismo.

[2] Lazar, H. (2000) In Search of a New Mission Statement for Canadian Fiscal Federalism. In: Lazar, H., Ed., Toward a New Mission Statement for Canadian Fiscal Federalism, Institute of Intergovernmental Relations, Kingston.

[3] Roy, B. (2009) Los Pilares de la Descentralización Fiscal. Perspectivas. Análisis de Temas Críticos para el Desarrollo Sostenible, Volume 7, Number 1, Corporación Andina de Fomento.

[4] Retchkiman, B. (1995) Aspectos estructurales de la economía pública. Textos Universitarios, UNAM, Mexico.

[5] Prest, A. (1981) Hacienda Pública. Editorial Gredos, Madrid.

[6] Almagro, M. (2013) El gravamen patrimonial de los vehículos e inmuebles por la haciendas locales. Una reforma en términos de sostenibilidad. In: Camacho, B. and Jiménez, O., Eds., Desarrollo regional sostenible en tiempos de crisis, Vol. 2, Chap. 21, University of Granada, Granada.

[7] Geffre, X. (2005) La Décentralisation. Éditions La Découverte, Paris.

[8] Bird, R.M. and Slack, E. (2004) International Handbook on Land and Property Taxation. Edward Elgar, Cheltenham. https://doi.org/10.4337/9781845421434

[9] Mullen, J. (1990) Property Tax Exemptions and Local Fiscal Stress. National Tax Journal, 43, 467-479.

[10] Stober, W.J. and Laurence, H. (1967) Property Tax Exemption: An Inefficient Subsidy to Industry. National Tax Journal, 2, 386-394.

[11] Kenyon, D.A., Langley, A.H. and Paquin, B.P. (2012) Property Tax Incentive Pitfalls. National Tax Journal, 65, 1011-1022. https://doi.org/10.17310/ntj.2012.4.14

[12] Bahl, R. and Martinez-Vazquez, J. (2008) The Determinants of Revenue Performance. In: Bahl, R., Youngman, J. and Martinez-Vazquez., J., Eds., Making Property Tax Work, Lincoln Institute of Land Policy, Cambridge, 35-57.

[13] Tello, C. (2013) Reforma Hacendaria Para Bienestar Social. In: Revista Economía UNAM, UNAM, Mexico, 24-51.

[14] López, A. (2014) Subcomité de Vigilancia del Sistema de Participaciones para los Municipios. In: Revista Hacienda Municipal, INDETEC, Mexico, 33-55.

[15] Astudillo, M. (2010) Las Transferencias Intergubernamentales en el Sistema Fiscal Francés. In: Dimensión económica, Vol. 2, Num. 4, IIE-UNAM, Mexico, 14-28.

[16] Gravelle, J. and Wallace, S. (2009) Overview of the Trends in Property Tax Base Erosion. In: Bell, M., et al., Eds., Erosion of the Property Tax Base, Trends, Causes and Consequences, Lincoln Institute of Land Policy, Cambridge.

[17] Ahmad, E., Brosio, G. and Pösch, C. (2014) Local Property Taxation and Benefits in Developing Countries-Overcoming Political Resistance? In: Ahmad, E. and Brosio, G., Eds., Handbook of Multilevel Finance, Edward Elgar, Cheltenham, 389-409.

[18] National Institute of Statistics and Geography (2014) Indicadores de Bienestar de las Entidades Federativas. http://www.beta.inegi.org.mx/app/bienestar/

[19] Haughwout, A. and Inman, R. (2002) Should Suburbs Help Their Central City. In: 
Gale, W.G. and Pack, J.T., Eds., Brookings- Wharton Papers on Urban Affairs 2002, Brookings Institution Press, Washington DC.

[20] Organization for Economic Cooperation and Development (2016) Taxation.

[21] Official Gazette of the Federation (1983) Decreto por el que se reforma y adiciona el artículo 115 de la Constitución Política de los Estados Unidos Mexicanos. http://www.diputados.gob.mx/LeyesBiblio/ref/dof/CPEUM_ref_103_03feb83.pdf

[22] Official Gazette of the Federation (1999) Decreto por el que se declara reformado y adicionado el artículo 115 de la de los Estados Unidos Mexicanos.

http://dof.gob.mx/nota_detalle.php?codigo $=4958409 \&$ fecha $=23 / 12 / 1999 \&$ print $=$ true

[23] Organization for Economic Cooperation and Development (2017) Tax on Property. https://data.oecd.org/tax/tax-on-property.htm

[24] Tax Coordination Law (2013). http://www.diputados.gob.mx/LeyesBiblio/ref/lcf/LCF_ref34_09dic13.pdf

[25] Canavire-Bacarreza, G. and Zúñiga, N. (2015) Transferencias e impuesto predial en México. In: Economía UNAM, Vol. 12, Num. 35, UNAM, Mexico, 69-99.

[26] State of Morelos Municipal Treasury Law (2014). https://www.hacienda.morelos.gob.mx/images/docu_planeacion/transparencia_fisc al/marco_regulatorio/Ley_General_de_Hacienda_del_Estado_de_Morelos.pdf

[27] El Universal (2015) Se supera meta de recaudación. 2.

[28] Fiscal Code of the Federal District (2014).

[29] (2014) State of Sinaloa Municipal Treasury Law. Official Gazette of the State of Sinaloa, No. 052 of 30 April 2014.

[30] (2014) State of Sonora Municipal Treasury Law. Official Gazette 47, Section III, 11 December 2014.

[31] (2015) State of Baja California Municipal Treasury Law. H. Congreso del Estado de Baja California. Secretaría de Servicios Parlamentarios Coordinación de Editorial y Registro Parlamentario Ultima Reforma P.O. No. 53, Secc. I, 20 November 2015. 


\section{Appendix}

\section{Databases}

Fiscal Code of the Federal District. (2014).

http://www.poderjudicialdf.gob.mx/work/models/PJDF/Transparencia/IPO/Art 14/Fr01/01Leyes/CFDF_2014-06-26.pdf, 15 September 2014.

Land Registry Institute of Sonora (2014) Information Obtained by Phone and e-Mail from Staff at the Land Registry Institute of Sonora.

Law to Promote Investment for the Economic Development of the State of Sinaloa. (2014).

www.ordenjuridico.gob.mx/Documentos/Estatal/Sinaloa/wo79044.doc, 15 June 2016.

Municipal Fiscal Code of Coahuila (2008).

https://mexico.justia.com/estados/coa/codigos/codigo-financiero-para-los-muni cipios-del-estado-de-coahuila-de-zaragoza/, 10 December 2015.

Municipal Fiscal Code of Chihuahua (2007).

http://www.municipiochihuahua.gob.mx/Transparencia/AD/82?file=CODIGO\% 20MUNICIPAL\%20PARA\%20EL\%20ESTADO\%20DE\%20CHIHUAHUA.pdf,

28 August 2017.

Municipal Fiscal Code of Tamaulipas (2016).

http://po.tamaulipas.gob.mx/wp-content/uploads/2016/08/Codigo_Municipal.p df, 10 March 2017.

Municipal Financial Code of Tlaxcala (2016).

http://www.congresotlaxcala.gob.mx/archivo/leyes/codigos/C005.pdf, 20 March 2016.

Municipal Land Registry of Baja California (2014) Information Obtained by Phone and e-Mail from Staff at the Land Registry of Baja California.

Municipal Tax Code of Veracruz (2012).

http://www.legisver.gob.mx/leyes/LeyesPDF/HACENMPAL05-02-12.pdf,

3 March 2015.

National Institute of Public Administration (2015) Diagnóstico y alternativas de solución para la Administración Pública Municipal. 2do Foro Estatal de Administradores Públicos, num. 169 México: INAP. 43-61.

National Institute of Statistics and Geography (2016) SIMBAD.

http://www.inegi.org.mx/sistemas/olap/Proyectos/bd/continuas/finanzaspublica s/FPMun.asp?s=est\&c=11289\&proy=efipem_fmun, 12 November 2017.

Political Constitution of the United Mexican States (2013).

http://www.diputados.gob.mx/LeyesBiblio/pdf/1.pdf, 13 March 2014.

State of Aguascalientes Municipal Treasury Law (2015).

http://www.aguascalientes.gob.mx/SEFI/catastro/leyes/LEY\%20DE\%20HACIEN DA\%20DEL\%20ESTADO\%20DE\%20AGUASCALIENTES.pdf, 24 June 2017.

State of Baja California Municipal Treasury Law (2015) H. Congreso del Estado de Baja California. Secretaría de Servicios Parlamentarios Coordinación de Editorial y Registro Parlamentario Ultima reforma P.O. No. 53, Secc. I, 20 Novem- 
ber 2015.

State of Baja California Sur Municipal Treasury Law (2014).

http://www.cbcs.gob.mx/index.php/cmply/1519-ley-hacienda-lapaz-bcs, 24 July 2017.

State of Campeche Municipal Treasury Law (2014).

http://www.ayuntamientodehopelchen.com/transparencia/assets/ley_hacienda_ municipios_estado_campeche.pdf, 24 January 2017.

State of Colima Municipal Treasury Law (2009).

http://www.procesadora.colima.gob.mx/documentos/ley_hda.pdf, 15 July 2015. State of Chiapas Municipal Treasury Law (1999).

https://tuxtla.gob.mx/admin/archivos/tuxtla/documentos/85d1da36_30052017_1 524.pdf, 10 January 2016.

State of Durango Municipal Treasury Law (2014).

http://congresodurango.gob.mx/Archivos/legislacion/LEY\%20DE\%20HACIEN DA\%20PARA\%20LOS\%20MUNICIPIOS.pdf, 25 March 2017.

State of Guanajuato Municipal Treasury Law (2016).

https://finanzas.guanajuato.gob.mx/c_legislacion/doc/leyes_estatales/10Ley_de_H acienda_para_los_Municipios_del_Estado_de_Guanajuato.pdf, 11 August 2016.

State of Guerrero Municipal Treasury Law (2011).

http://i.guerrero.gob.mx/uploads/2006/02/LHM677.pdf, 10 December 2015.

State of Hidalgo Municipal Treasury Law (2006).

http://docs.mexico.justia.com.s3.amazonaws.com/estatales/hidalgo/ley-de-hacie nda-municipal-para-el-estado-de-hidalgo.pdf, 29 November 2016.

State of Jalisco Municipal Treasury Law (1984).

https://transparencia.info.jalisco.gob.mx/sites/default/files/Ley\%20de\%20Hacien da\%20Municipal\%20del\%20Estado\%20de\%20Jalisco_3.pdf, 20 March 2016.

State of México Municipal Treasury Law (1988).

http://legislacion.edomex.gob.mx/sites/legislacion.edomex.gob.mx/files/files/pdf /ley/abr/leyabr040.pdf, 18 June 2015.

State of Michoacán Municipal Treasury Law (2014).

http://transparencia.congresomich.gob.mx/media/documentos/trabajo_legislativo/ ley_de_hacienda_municipal_del_estado_25_de_diciembre_de_2014.pdf, 3 March 2017.

State of Morelos Municipal Treasury Law (2014).

https://www.hacienda.morelos.gob.mx/images/docu_planeacion/transparencia_fis cal/marco_regulatorio/Ley_General_de_Hacienda_del_Estado_de_Morelos.pdf, 24 June 2015.

State of Nayarit Municipal Treasury Law (1994).

http://www.ordenjuridico.gob.mx/Estatal/NAYARIT/Municipios/NAYMPLey1. pdf, 1 May 2017.

State of Nuevo León Municipal Treasury Law (2014).

http://www.guadalupe.gob.mx/ley-de-hacienda-para-los-municipios-del-estadode-nuevo-leon-periodico-oficial-del-estado-29-de-diciembre-de-2014/,

24 December 2016. 
State of Oaxaca Municipal Treasury Law (2000).

http://www.ordenjuridico.gob.mx/Estatal/OAXACA/Municipios/OAMPLey4.pdf, 1 January 2017.

State of Puebla Municipal Treasury Law (2013).

http://www.auditoriapuebla.gob.mx/images/LEYES/SEGUNDO/ley_de_haciend a_municipal_del_edo_de_puebla\%2030\%20dic\%2013.pdf, 20 March 2017.

State of Queretaro Municipal Treasury Law (2009).

http://www.elmarques.gob.mx/wp-content/uploads/2014/10/81-LEY_HACIEN

DA_MUNICIPIOS.pdf, 21 March 2017.

State of Quintana Roo Municipal Treasury Law (2014).

http://www.aseqroo.gob.mx/MARCO_JURIDICO/Leyes/02\%20Ley\%20de\%20H acienda\%20de\%20los\%20Municipios.pdf, 31 December 2016.

State of San Luis Potosí Municipal Treasury Law (2014).

http://www.ordenjuridico.gob.mx/Documentos/Estatal/San\%20Luis\%20Potosi/ wo95895.pdf, 14 February 2016.

State of Sinaloa Municipal Treasury Law (2014) Official Gazette of the State of Sinaloa, No. 052 of 30 April 2014.

State of Sonora Municipal Treasury Law (2014) Official Gazette 47, section III, 11 December 2014.

State of Tabasco Municipal Treasury Law (2013).

http://tsj-tabasco.gob.mx/documentos/3472/LEY-DE-HACIENDA-MUNICIPA L/, 1 May 2015.

State of Yucatán Municipal Treasury Law (2015).

https://poderjudicialyucatan.gob.mx/digestum/marcoLegal/02/2015/DIGESTU M02328.pdf, 18 June 2016.

State of Zacatecas Municipal Treasury Law (2013).

http://www.congresozac.gob.mx/e/articulo\&art=37226\&ley=20\&tit=0\&cap=0\&s ec=1, 22 December 2016. 